\title{
A RESPONSABILIDADE CIVIL POR REPARAÇÃO DE DANOS AMBIENTAIS OCORRIDOS EM ÁREA DE PROTEÇÃO AMBIENTAL E O PARADOXO COM O DIREITO FUNDAMENTAL À MORADIA DIGNA
}

\section{THE LIABILITY OF ENVIRONMENTAL DAMAGE REPAIR OCCURRED IN THE ENVIRONMENTAL PROTECTION AREA AND THE PARADOX WITH THE FUNDAMENTAL RIGHT TO DECENT HOUSING}

\author{
${ }^{1}$ Elcio Nacur Rezende \\ ${ }^{2}$ Ariel Augusto Pinheiro dos Santos
}

\section{RESUMO}

$\mathrm{O}$ artigo trata de responsabilização daquele que promove dano ambiental em determinada Área de Proteção Ambiental. Discutimos os paradoxos existentes quando a degradação ambiental é causada por atos decorrentes da instalação de moradia em áreas ambientalmente protegidas. Abordamos o histórico, a formas de responsabilização no direito brasileiro, além das teorias do risco. Analisamos também a obrigatoriedade do Estado de promover políticas públicas para a implementação do direito fundamental social à moradia digna. Não obstante, foi feita uma reflexão sobre as características constantes na visão sustentável de mundo, informando uma nova concepção que auxiliará na busca do objetivo do texto. Também tratamos do tema unidade de conservação proposto pela Lei 9.985 de 2000.

Palavras-chave: Responsabilização civil, Dano ambiental, Direito a moradia, Área de proteção ambiental, Sustentabilidade

\begin{abstract}
Accountability it from that article which promotes environmental damage in particular the Environmental Protection Area. We discuss existing paradoxes when environmental degradation caused and by acts arising from housing installation in environmentally protection area. We approach the historical, accountability forms in brazilian law, beyond the theories of risk. Also analyzed the obligation of the State to promote public policies for the implementation of the right fundamental social decent housing. Nevertheless, it was made a reflection on the constants in the world sustainable vision, informing a new design will assist in the search to text purpose. We deal also do theme conservation area proposed by Law 9985
\end{abstract}

Keywords: Civil liability, Environmental damage, Right to housing, Environmental protection area, Sustainability

\footnotetext{
${ }^{1}$ Doutor em Direito pela Pontifícia Universidade Católica de Minas Gerais - PUC, Minas Gerais (Brasil). Professor em Direito pela Escola Superior Dom Helder Câmara - ESDHC, Minas Gerais (Brasil).

E-mail: elcionrezende@yahoo.com.br

${ }^{2}$ Mestranda em Direito Ambiental e Desenvolvimento Sustentável pela Escola Superior Dom Helder Câmara ESDHC, Minas Gerais (Brasil). Estagiária pela Universidade Federal de Minas Gerais - UFMG, Minas Gerais (Brasil). E-mail: ariel5002@ hotmail.com
} 


\section{INTRODUÇÃO}

Tendo em vista a mudança paradigmática ocorrida após Estocolmo-1972 o dano ambiental deixa de ser enxergado como algo comum da sociedade e propulsor do desenvolvimento econômico, para uma conduta repreendida pela sociedade civil e penalizada pelo Estado. Cabe agora à procura do responsável civilmente para a reparação integral do bem ambiental ou na impossibilidade, a indenização para todos que sofreram a perda.

Essa nova forma de pensar o desenvolvimento pode entrar em choque quando o dano decorre da busca de outros direitos assegurados constitucionalmente e alvo de inúmeras lutas sociais. Assim no momento que o indivíduo provocar um dano ambiental durante a busca da implementação de um direito, a ele privado, ficará a pergunta do responsável pela reparação da perda.

O legislador pátrio com o intuito de proteger determinadas áreas com maior disposição, concedeu um regime jurídico diferenciado para essas localidades. Em alguns casos poderão ser exploradas sustentavelmente, cabendo ao proprietário a defesa do Direito de Meio Ambiente Ecologicamente Equilibrado conjugado com o desenvolvimento econômico. Na hipótese de o dano ambiental ocorrer nessas áreas e a razão for a busca por um direito constitucionalmente assegurado, estaremos diante de uma situação capciosa.

$\mathrm{O}$ artigo trata justamente dessas situações capciosas. Foram debatidos a responsabilidade civil ambiental para a reparação de uma Área de Proteção Ambiental (APA) durante a busca pelo Direito à Moradia Digna.

Foi tratado inicialmente a questão da responsabilidade civil e suas adequações ao dano ambiental. Após abordamos o Direito Fundamental à Moradia Digna e suas caracterizações. Debateremos também a necessidade de uma cosmovisão sustentável para a situação ora em questão. Analisamos os caracteres jurídicos das unidades de conservação, especialmente a APA. Por fim discutimos quem é o responsável civilmente pela reparação ambiental quando o dano decorrer de busca pelo direito à moradia.

\section{RESPONSABILIDADE CIVIL}

O direito é considerado um instrumento de pacificação social, isto é, tenta evitar e resolver conflitos entre os cidadãos para que possam viver em paz e harmonia. Assim caso 
alguém viole a paz de outro deve restaurar o status quo para que a paz volte a reinar na comunidade.

Percebemos que evitar a ação danosa e promover a reparação são pilares do direito. Esta é a linha de raciocínio da Responsabilidade Civil, que pode ser conceituada como a imputação de um dever de reparar ou na impossibilidade de indenizar outrem por uma conduta danosa ${ }^{1}$. Nota-se que a preferência é a reparação da coisa, contudo em determinadas circunstâncias fáticas, isso será impossível, assim deverá proceder a avaliação do bem danificado ou perecido e entregar a quantia em dinheiro para a pessoa que experimentou a perda. Outra premissa digna de nota é a possibilidade de existir responsabilidade civil de uma conduta lícita, isto é, mesmo que o indivíduo siga a lei, deverá indenizar outro².

Os requisitos gerais da responsabilidade civil são: a conduta, o nexo causal, o dano, culpa/dolo. Cavalieri (2012, p. 25) conceitua conduta como “comportamento humano voluntário que se exterioriza através de uma ação ou omissão, produzindo consequências jurídicas”. O mesmo doutrinador conceitua nexo como o liame da conduta do agente com o dano. Assim na seara civil o indivíduo que praticar uma conduta ilícita sem ligação com ao dano não será responsabilizado. O dano é o decréscimo patrimonial ou extrapatrimonial que a vítima sofre. A culpa em sentido estendido abrange a culpa em sentido estrito e o dolo. O primeiro refere-se à negligência, imprudência e imperícia, já o segundo a vontade inequívoca do agente em praticar o dano. Na seara civil essa diferenciação é praticamente irrelevante, ao contrário do âmbito penal, em que se pune o dolo de maneira mais rígida.

A diferenciação entre a responsabilidade civil subjetiva e objetiva é um ponto central na doutrina civilista. A principal diferença é a perquirição de culpa na primeira e a prescindibilidade na segunda ${ }^{3}$.

\footnotetext{
1 "Art. 927. Aquele que, por ato ilícito (arts. 186 e 187), causar dano a outrem, fica obrigado a repará-lo" (BRASIL, 2002).

2 "Art. 187. Também comete ato ilícito o titular de um direito que, ao exercê-lo, excede manifestamente os limites impostos pelo seu fim econômico ou social, pela boa-fé ou pelos bons costumes” (BRASIL, 2002).

3 “A ideia de culpa está visceralmente ligada à responsabilidade, por isso que, de regra, ninguém pode merecer censura ou juízo de reprovação sem que tenha faltado com o dever de cautela em seu agir. Daí ser a culpa, de acordo com a teoria clássica, o principal pressuposto da responsabilidade civil subjetiva.

O Código Civil de 2002, em seu art. 186 (art. 159 do Código Civil de 1916), manteve a culpa como fundamento da responsabilidade subjetiva. A palavra culpa está sendo aqui empregada em sentido amplo, Iara sensu, para indicar não só a culpa stricto sensu, como também o dolo" (CAVALIERI FILHO, p.17).
} 


\subsection{Responsabilidade Civil Objetiva e o Direito Ambiental}

Na responsabilidade civil objetiva os caracteres para sua identificação são a conduta, o nexo e o dano. O agente que praticar uma conduta que resulte em um dano deverá repará-lo independentemente de culpa/dolo em sua conduta. Essa modalidade é considerada exceção no ordenamento jurídico brasileiro, sendo regra a responsabilidade subjetiva. Apenas em hipóteses excepcionais deverá dispensar a perquirição de culpa.

No direito brasileiro, em matéria ambiental, adota-se a responsabilidade civil objetiva, tendo em vista o Princípio Protetor do Meio Ambiente presente no artigo $225^{4}$ da Constituição da República Federativa do Brasil e principalmente o artigo 14 § $1^{\circ}$ da Lei 6938 de 1981, denominada Lei de Política Nacional do Meio Ambiente:

$\S 1^{\circ}$ - Sem obstar a aplicação das penalidades previstas neste artigo, é o poluidor obrigado, independentemente da existência de culpa, a indenizar ou reparar os danos causados ao meio ambiente e a terceiros, afetados por sua atividade. O Ministério Público da União e dos Estados terá legitimidade para propor ação de responsabilidade civil e criminal, por danos causados ao meio ambiente (BRASIL,1981) (grifo nossos).

$\mathrm{O}$ artigo retirou qualquer possibilidade de debate sobre qual responsabilidade aplicar, uma vez que deixou de incluir como caractere da responsabilidade civil ambiental a culpa. Assim todo agente que praticar uma conduta que leve a um dano ambiental deverá reparar ou indenizar, sem a necessidade de provar culpa. Convém elucidar porque houve a opção da responsabilidade objetiva.

Qualquer indivíduo que conhece a atividade processual sabe da dificuldade em se produzir prova, às vezes é impossível sua constituição senão é extremante difícil. A título de curiosidade o novo Código de Processo Civil criou o instituto chamado distribuição dinâmica do ônus da prova, o juiz poderá inverter o ônus da prova caso uma parte tenha mais facilidade de produzi-la 5 .

Tendo em vista a dificuldade de produzir prova e necessidade de atribuir a um indivíduo a responsabilidade de reparação do dano ambiental, convencionou acertadamente a

\footnotetext{
4 “Art. 225. Todos têm direito ao meio ambiente ecologicamente equilibrado, bem de uso comum do povo e essencial à sadia qualidade de vida, impondo-se ao Poder Público e à coletividade o dever de defendê-lo e preservá- lo para as presentes e futuras gerações" (BRASIL, 1988).

5 “Art. $373 \S 1$ o Nos casos previstos em lei ou diante de peculiaridades da causa relacionadas à impossibilidade ou à excessiva dificuldade de cumprir o encargo nos termos do caput ou à maior facilidade de obtenção da prova do fato contrário, poderá o juiz atribuir o ônus da prova de modo diverso, desde que o faça por decisão fundamentada, caso em que deverá dar à parte a oportunidade de se desincumbir do ônus que lhe foi atribuído" (BRASIL, 2015).
} 
responsabilidade civil objetiva, descartando a necessidade de comprovar a culpa e impedindo que a reparação do dano seja socializada pela dificuldade de produção de prova sobre a culpa.

\subsection{Teorias do Risco}

O debate agora recai sobre o nexo causal. O direito elenca determinadas situações como rompedoras do liame, isto é, determinados eventos podem destruir a ligação da conduta com o resultado. Há uma discussão teórica sobre a possibilidade de exclusão dessas situações em matérias de defesa. Uma corrente prega que poderão ser arguidas as rompedoras do nexo de causalidade e a outra que não poderão ser arguidas, em virtude da situação fática. Salientamos que a escolha de uma corrente não é apenas uma atividade de direito material, uma vez que, dependendo da escolha teórica ficará a matéria de defesa diminuta. Assim deve- se escolher a corrente com a máxima parcimônia, uma vez que direitos constitucionais relativos ao devido processo legal poderão ser tolhidos.

\subsubsection{Teoria do Risco Integral}

Nesta Teoria não é aceito qualquer excludente do nexo causal, assim se um fato da natureza imprevisível provocar um dano em uma atividade explorada por indivíduo, este será civilmente responsável de reparar o dano, não cabendo nenhuma das modalidades rompedoras do nexo causal. O magistrado que entende desta maneira caberá à parte alegar apenas que não existiu o dano ou posteriormente tentar uma ação de regresso.

A Denunciação a Lide não está sendo aceita pelos tribunais, uma vez que traz para discussão a culpa em uma ação de responsabilidade objetiva ${ }^{6}$. Isso poderia inviabilizar a tutela jurisdicional de proteção ambiental.

A aplicação mais prudente desta teoria seria apenas nas atividades de risco, uma vez que o empreendedor está assumindo o risco de produzir um dano ambiental para ter um lucro maior. Deve-se ter cuidado na aplicação desta teoria principalmente na questão atinente a atividade de risco. Não há um rol taxativo no direito brasileiro de quais atividades são efetivamente de risco, cabendo ao julgador à aferição no caso concreto.

\footnotetext{
6 "Processual civil. Ação Civil Pública. Dano Ambiental. 1. É parte legítima para figurar no pólo passivo da Ação Civil Pública a pessoa jurídica ou física apontada como tendo praticado o dano ambiental. 2. A Ação Civil Pública deve discutir, unicamente, a relação jurídica referente à proteção do meio ambiente e das suas conseqüências pela violação a ele praticada. 3. Incabível, por essa afirmação, a denunciação da lide. 4 . Direito de regresso, se decorrente do fenômeno de violação ao meio ambiente, deve ser discutido em ação própria. 5. As questões de ordem pública decididas no saneador não são atingidas pela preclusão. 6. Recurso especial improvido" Recurso Especial nº 232187 / SP (BRASIL, 2000) (grifo nossos).
} 


\subsubsection{Teoria do Risco Criado (Teoria do Risco Proveito)}

Esta teoria em contraponto a primeira informa que será responsabilizado civilmente quem criar tal risco, cabendo assim as excludentes de nexo causal. Portanto pode ser considera mais benéfica ao poluidor, uma vez que terá matérias de defesas robustas e não apenas a negativa da existência do dano ou a falta de conduta.

Parece muito mais equilibrado a utilização desta teoria em atividade que não são de risco, uma vez que responderão objetivamente (independentemente de culpa/dolo), contudo poderão utilizar as alegações de força maior/caso fortuito, culpa de terceiro, entre outros. Equilibraria os direitos a ampla defesa e a efetividade da tutela ambiental.

\subsubsection{Posições dos Tribunais}

Havia um debate sobre qual teoria aplicar. Contudo no ano de 2014 o egrégio Superior Tribunal de Justiça aplicou Teoria do Risco Integral ${ }^{7}$, relegando a discussão sobre as matérias rompedoras do liame de causalidade.

\section{DIREITO À MORADIA}

A CFRB/88 em seu artigo primeiro elencou a Dignidade da Pessoa Humana ${ }^{8}$ como um princípio orientador de toda atividade estatal ou particular. Impôs a necessidade de tratamento de forma digna para toda pessoa (brasileiro ou estrangeiro), impedindo assim

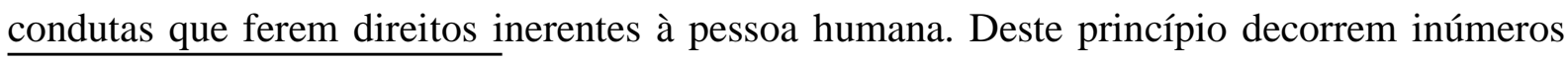

\footnotetext{
7 "Responsabilidade civil por dano ambiental. Recurso especial representativo de controvérsia. Art. 543-c do CPC. Danos decorrentes do rompimento de barragem. Acidente ambiental ocorrido, em janeiro de 2007, nos municípios de Miraí e Muriaé, estado de Minas Gerais. Teoria do Risco Integral. Nexo de Causalidade.

1. Para fins do art. 543-C do Código de Processo Civil: a) a responsabilidade por dano ambiental é objetiva, informada pela teoria do risco integral, sendo o nexo de causalidade o fator aglutinante que permite que o risco se integre na unidade do ato, sendo descabida a invocação, pela empresa responsável pelo dano ambiental, de excludentes de responsabilidade civil para afastar sua obrigação de indenizar; b) em decorrência do acidente, a empresa deve recompor os danos materiais e morais causados e c) na fixação da indenização por danos morais, recomendável que o arbitramento seja feito caso a caso e com moderação, proporcionalmente ao grau de culpa, ao nível socioeconômico do autor, e, ainda, ao porte da empresa, orientando-se o juiz pelos critérios sugeridos pela doutrina e jurisprudência, com razoabilidade, valendo-se de sua experiência e bom senso, atento à realidade da vida e às peculiaridades de cada caso, de modo que, de um lado, não haja enriquecimento sem causa de quem recebe a indenização e, de outro, haja efetiva compensação pelos danos morais experimentados por aquele que fora lesado. 2. No caso concreto, recurso especial a que se nega provimento" Recurso Especial 1374284 / MG (BRASIL, 2014). (grifo nossos)

8 “Art. $1^{\circ}$ A República Federativa do Brasil, formada pela união indissolúvel dos Estados e Municípios e do Distrito Federal, constitui-se em Estado Democrático de Direito e tem como fundamentos:

I - a soberania;

II - a cidadania

III - a dignidade da pessoa humana;

IV - os valores sociais do trabalho e da livre iniciativa;

V - o pluralismo político" (BRASIL, 1988).
}

Revista de Direito e Sustentabilidade | e-ISSN: 2525-9687 | Minas Gerais | v. 1 | n. 2 | p. 287-302 | Jul/Dez. 2015. 
direitos civis, políticos e sociais nos termos de Marshall (1967), sendo a moradia um desdobramento lógico.

É impossível falar em vivência digna do ser humano sem um local para descansar e recuperar as energias após um longo dia de trabalho. Assim está arrolado no artigo $6^{\circ}$ da CRFB $/ 88^{9}$ a Moradia como um Direito Fundamental Social, cabendo a República Federativa do Brasil promover políticas públicas para efetivar o direito constante na Carta Magna.

Após a CRFB/88 o Estado (entendendo União, estados, municípios e Distrito Federal) promoveu inúmeras políticas públicas com o intuito de solidificar esse direito social. No âmbito federal podemos citar a Lei 11.977 de 2009 denominada Lei da Minha Casa Minha $\mathrm{Vida}^{10}$ que tem por objetivo fornecer ou financiar casas populares para determinadas faixas de renda ou ainda podemos considerar a Reforma Agrária ${ }^{11}$ como fixador do homem à terra, concedendo uma moradia e local para o trabalho. No município de Belo Horizonte podemos citar o programa Vila Viva ${ }^{12}$ que discute junto com a comunidade formas de urbanizar as vilas e favelas. Ressaltamos que o Direito Constitucional à Moradia não é apenas uma cama com um teto tosco. A moradia deverá apresentar condições para os exercícios inerentes à personalidade humana ${ }^{13}$. Utilizaremos para conceituar a dignidade do imóvel os institutos do direito de vizinhança, a saber, segurança, sossego e salubridade. Toda moradia deverá apresentar um sistema de proteção contra eventuais invasores e defesa da intimidade dos

\footnotetext{
9 “Art. $6^{\circ}$ São direitos sociais a educação, a saúde, a alimentação, o trabalho, a moradia, o lazer, a segurança, a previdência social, a proteção à maternidade e à infância, a assistência aos desamparados, na forma desta Constituição" (BRASIL, 1988).

10 “Art. 1o O Programa Minha Casa, Minha Vida - PMCMV tem por finalidade criar mecanismos de incentivo à produção e aquisição de novas unidades habitacionais ou requalificação de imóveis urbanos e produção ou reforma de habitações rurais, para famílias com renda mensal de até $\mathrm{R} \$ 4.650,00$ (quatro mil, seiscentos e cinquenta reais) e compreende os seguintes subprogramas:

I - o Programa Nacional de Habitação Urbana - PNHU; e II - o Programa Nacional de Habitação Rural - PNHR" (BRASIL, 2009).

11 “Art. 184. Compete à União desapropriar por interesse social, para fins de reforma agrária, o imóvel rural que não esteja cumprindo sua função social, mediante prévia e justa indenização em títulos da dívida agrária, com cláusula de preservação do valor real, resgatáveis no prazo de até vinte anos, a partir do segundo ano de sua emissão, e cuja utilização será definida em lei” (BRASIL, 1988).

12 "O Vila Viva engloba obras de saneamento, remoção de famílias, construção de unidades habitacionais, erradicação de áreas de risco, reestruturação do sistema viário, urbanização de becos, implantação de parques e equipamentos para a prática de esportes e lazer. Após o término da urbanização, a área será legalizada com a emissão das escrituras dos lotes aos ocupantes" (BELO HORIZONTE, 2015).

13 "O direito à moradia é um direito complexo, rico em atribuições, que vai além do direito de ter uma casa própria, embora este seja um complemento indispensável para a efetivação desse direito. Não possui apenas a conotação de habitação, mas envolve diretamente a qualidade de vida, dotada de condições adequadas de higiene e conforto, e que preserve a intimidade pessoal e a privacidade familiar. Em suma, requer uma habitação digna e adequada" (RANGEL; SILVA 2009, p.65).
} 
moradores, deverá também ser tranquila para a prática de atividades e descanso, além de higiênico para conservar a saúde dos habitantes ${ }^{14}$.

Mesmo com essas políticas públicas e o relativo lapso de tempo desde a CRFB/88 podemos dizer que tal direito ainda não foi plenamente efetivado, existindo ainda um déficit de moradia ${ }^{15}$, incumbindo o Poder Público de e implementar tal direito. Salientamos que isso ainda é alvo de inúmeras lutas de movimentos sociais como o Movimento dos Sem-Teto.

Nesse sentido todos (cidadãos e estrangeiros) ${ }^{16}$ têm o Direito Fundamental a Moradia devendo esta ser concedida ou facilitada pelo Poder Público, devendo respeitar o Sossego, a Segurança e a Salubridade dos residentes e vizinhos, para a efetivação parcial do disposto no artigo $1^{\mathrm{o}}$ inc, III da CRFB/88.

\section{SUSTENTABILIDADE}

A Sustentabilidade sempre foi vista a partir do tripé Proteção Ambiental, Desenvolvimento Econômico e Equidade ${ }^{17}$. O direito à moradia está profundamente ligado com o último, como já dito a moradia é algo básico para dignidade da pessoa humana e forma de diminuir as diferenças sociais. Ocorre que Juarez Freitas (2011, p.55) em seu livro Sustentabilidade Direito ao Futuro elenca cinco dimensões da Sustentabilidade ${ }^{18}$. Além das três tradicionais arrola ainda a Dimensão Ética e a Jurídica-Política.

14 “Art. 1.277. O proprietário ou o possuidor de um prédio tem o direito de fazer cessar as interferências prejudiciais à segurança, ao sossego e à saúde dos que o habitam, provocadas pela utilização de propriedade vizinha" (BRASIL, 2002).

15 “O censo demográfico 2010 aponta um déficit habitacional de 6,490 milhões de unidades, o correspondente a 12,1\% dos domicílios do país (tabela 1). Em termos absolutos, o déficit é menor nas áreas metropolitanas do que nas não metropolitanas. A região Sudeste concentra $38 \%$ do déficit habitacional do país, o que corresponde a 2,674 milhões de unidades, mais da metade (1,495 milhões) em São Paulo. Outros 30\% do déficit habitacional vem da região Nordeste, com destaque para os estados do Maranhão e da Bahia, com 421 mil e 521 mil unidades, respectivamente. A região Centro-Oeste apresenta o menor déficit habitacional do Brasil, cerca de 560 mil unidades" (FUNDAÇÃO JOÃO PINHEIRO, 2013, p. 28).

16 “Art. $5^{\circ}$ Todos são iguais perante a lei, sem distinção de qualquer natureza, garantindo-se aos brasileiros e aos estrangeiros residentes no País a inviolabilidade do direito à vida, à liberdade, à igualdade, à segurança e à propriedade, nos termos seguintes" (BRASIL, 1988).

17 "1. O homem é ao mesmo tempo obra e construtor do meio ambiente que o cerca, o qual lhe dá sustento material e lhe oferece oportunidade para desenvolver-se intelectual, moral, social e espiritualmente. Em larga e tortuosa evolução da raça humana neste planeta chegou-se a uma etapa em que, graças à rápida aceleração da ciência e da tecnologia, o homem adquiriu o poder de transformar, de inúmeras maneiras e em uma escala sem precedentes, tudo que o cerca. Os dois aspectos do meio ambiente humano, o natural e o artificial, são essenciais para o bem-estar do homem e para o gozo dos direitos humanos fundamentais, inclusive o direito à vida mesma. 2. A proteção e o melhoramento do meio ambiente humano é uma questão fundamental que afeta o bem-estar dos povos e o desenvolvimento econômico do mundo inteiro, um desejo urgente dos povos de todo o mundo e um dever de todos os governos" (ONU, 1972).

18 “A sustentabilidade precisa, então, ser assimilada em sua complexidade poliédrica. Não pode ser vítima de enfoques banalizantes e dos reducionismos extremos. 
A primeira refere-se a um nexo entre todos os seres e a natureza, cabendo assim um dever subjetivo de proteção mútua. Os seres de maior racionalidade deverão vigiar os seres de menor racionalidade, com o intuído de promover uma ecosfera equilibrada.

Já segunda dimensão diz que a Sustentabilidade é um dever constitucional do Estado e de cada cidadão, promovendo assim a construção do "Estado Sustentável”. Desta dimensão decorre inúmeros princípios, sendo um deles à Moradia Digna e Segura, que compreende a possibilidade de residir em um local seguro e salubre. Percebemos que o direito à moradia digna está intimamente ligado a duas dimensões da Sustentabilidade de Freitas (2011, p.63).

\section{5. ÁREA DE PROTEÇÃO AMBIENTAL}

Toda área deve ser preservada, contudo determinadas áreas são mais suscetíveis à destruição ecológica e outras protegidas em sua totalidade. Isso ocorre pela diferença da utilização do meio ambiente pelo homem, na qual cada área terá sua destinação. Assim uma área industrial, via de regra, é plenamente degradada. Cabe então ao poder público e a sociedade civil a delimitação das atividades em cada área para proteção do meio ambiente e também para o respeito ao direito de vizinhança.

Assim no uso de suas atribuições o legislador ordinário expediu a Lei 9985 de Julho de 2000, também chamada Lei do Sistema Nacional de Unidade de Conservação - SUNC ${ }^{19}$. Coloca no ordenamento jurídico brasileiro institutos importantes para a proteção ambiental divididos em duas categorias: Unidades de Proteção Integral ${ }^{20}$ e Unidades de Uso Sustentável $^{21}$. A missão da primeira é a proteção da natureza excepcionalmente haverá algumas hipóteses de exploração indireta. Já a segunda compatibiliza a preservação ambiental com o desenvolvimento sustentável. A Área de Proteção Ambiental - APA está no rol de unidades de uso sustentável ${ }^{22}$.

\footnotetext{
Há sem hierarquia rígida e sem caráter exaustivo, pelo menos, cinco dimensões da sustentabilidade, mais ou menos entrelaçadas como galhos da mesma árvore(...)” (FREITAS, 2011, p. 55).

19 “Art. $2^{\circ}$ inc. I - unidade de conservação: espaço territorial e seus recursos ambientais, incluindo as águas jurisdicionais, com características naturais relevantes, legalmente instituído pelo Poder Público, com objetivos de conservação e limites definidos, sob regime especial de administração, ao qual se aplicam garantias adequadas de proteção" (BRASIL, 2000).

20 "Art. $2^{\circ}$ inc. VI - proteção integral: manutenção dos ecossistemas livres de alterações causadas por interferência humana, admitido apenas o uso indireto dos seus atributos naturais" (BRASIL, 2000)

21 “Art. $2^{\circ}$ inc. XI - uso sustentável: exploração do ambiente de maneira a garantir a perenidade dos recursos ambientais renováveis e dos processos ecológicos, mantendo a biodiversidade e os demais atributos ecológicos, de forma socialmente justa e economicamente viável" (BRASIL, 2000).

22 “Art. 14. Constituem o Grupo das Unidades de Uso Sustentável as seguintes categorias de unidade de conservação:
} 
O Artigo 15 da lei diz:

A Área de Proteção Ambiental é uma área em geral extensa, com um certo grau de ocupação humana, dotada de atributos abióticos, bióticos, estéticos ou culturais especialmente importantes para a qualidade de vida e o bem-estar das populações humanas, e tem como objetivos básicos proteger a diversidade biológica, disciplinar o processo de ocupação e assegurar a sustentabilidade do uso dos recursos naturais.

$\S 1$ 을 A rea de Proteção Ambiental é constituída por terras públicas ou privadas.

$\S 2$ - Respeitados os limites constitucionais, podem ser estabelecidas normas e restrições para a utilização de uma propriedade privada localizada em uma Área de Proteção Ambiental.

§ 3ํㅗ As condições para a realização de pesquisa científica e visitação pública nas áreas sob domínio público serão estabelecidas pelo órgão gestor da unidade.

$\S 4^{\circ} \mathrm{Nas}$ áreas sob propriedade privada, cabe ao proprietário estabelecer as condições para pesquisa e visitação pelo público, observadas as exigências e restrições legais.

§ 5o A Área de Proteção Ambiental disporá de um Conselho presidido pelo órgão responsável por sua administração e constituído por representantes dos órgãos públicos, de organizações da sociedade civil e da população residente, conforme se dispuser no regulamento desta Lei (BRASIL, 2000) (grifo nosso).

A primeira lição que retiramos deste artigo é o tamanho da área, deve ser considerada extensa. Isso será aferido no caso concreto sendo que os costumes da região deverão constar como parâmetro. Outra lição é a existência de um assentamento humano, todavia não deverá ser grande o suficiente para inviabilizar a preservação ambiental. Percebemos também a possibilidade de ser constituída em terras públicas ou privadas. Poderá ser um espaço para o desenvolvimento de pesquisas e visitação do público. $\mathrm{O}$ instituto foi desenhado para atender os requisitos do desenvolvimento sustentável, uma vez que preserva a natureza, promove uma ocupação humana com possibilidade de desenvolvimento econômico, contemplando assim o tripé tradicional de sustentabilidade.

Na concepção de Freitas (2011, p. 57) a relação entre os seres proposto pela APA reafirma a dimensão ética da sustentabilidade. Além de preencher logicamente a dimensão Jurídica-Política uma vez que vários princípios decorrentes da sustentabilidade podem ser percebidos na APA.

Verificamos que a introdução no ordenamento jurídico brasileiro da APA se mostrou favorável, mostrando um instituto que tenta conciliar a preservação ambiental com o assentamento humano.

I - Área de Proteção Ambiental;

II - Área de Relevante Interesse Ecológico;

III - Floresta Nacional;

IV - Reserva Extrativista;

V - Reserva de Fauna;

VI - Reserva de Desenvolvimento Sustentável; e

VII - Reserva Particular do Patrimônio Natural” (BRASIL, 2000). 


\section{RESPONSABILIDADE DOS OCUPANTES EM APA}

Após o estudo sobre os conteúdos relevantes para compreensão do tema discutiremos, se os ocupantes de uma Área de Proteção Ambiental têm responsabilidade sobre eventuais danos causados ao meio ambiente.

Como dito anteriormente na APA existe uma ocupação humana, sendo que a gleba de terra pode ter caráter público ou particular. Assim criaremos o grupo de ocupantes de APA em terra pública e os ocupantes de APA em terra particular. Tendo em vista as particularidades os casos serão analisados em separado.

\subsection{Responsabilidade de Ocupantes de APA particular}

Existe no Direito pátrio a responsabilização do proprietário do prédio por coisas caídas ou ruína, além disso, por eventuais atividades nocivas aos vizinhos. Demostra, portanto, que é aceito a responsabilidade civil do proprietário em algumas situações. Ocorre que essas hipóteses do direito civil as atividades danosas atingem outro prédio ou transeunte, no caso estudado o dano é na própria propriedade. Salientamos que o dano ambiental é difuso, ou seja, ainda que circunscrito a uma localidade (propriedade degradada), toda a coletividade sofrerá a perda.

A Lei do SNUC permite o uso sustentável da APA, possibilitando assim a pesquisa científica e a visitação. A lei permite que os proprietários regulem tais atividades, respeitando as restrições legais. Pela Teoria do Risco Integral caso um pesquisador ou um visitante provocasse o dano na APA, o proprietário não poderia alegar culpa de terceiro e seria responsabilizado civilmente pelo dano ambiental, uma vez que não são aceitas as excludentes do nexo causal. Caso optasse pela Teoria do Risco Criado permitiria a quebra no nexo de causalidade, retirando a responsabilidade do dono da terra. Como já esposado anteriormente o risco da atividade pode ser o ponto de escolha de qual teoria aplicar. Caso o intérprete da lei entendesse que a permissão de pesquisa e visitação em APA é uma atividade de risco poderia aplicar a teoria do risco integral, caso entendesse que não há risco e por medida de equidade aplicaria a teoria do risco criado.

Nessa situação dificilmente falaremos de dano decorrente da implementação do Direito à Moradia, uma vez que o proprietário na maioria dos casos tem a possibilidade de construir no terreno e independentemente da participação estatal. No caso excepcionalíssimo 
de ocorrer um dano terá bens para satisfazer essa obrigação, contudo deverá respeitar a impenhorabilidade de determinados bens.

Percebemos assim que a escolha da aplicação da teoria é um ponto central na responsabilização dos ocupantes de APA em terra particular.

\subsection{Responsabilidade de Ocupantes de APA em terra pública}

O direito como dito anteriormente é um mecanismo de pacificação social, hoje uma das maiores disputas sociais é a questão da moradia. Mesmo existindo o dever constitucional de o Estado proporcionar tal direito fundamental social, existem casos de autotutela para implementar tal direito. Esses casos de autotutela são recorrentemente chamados de invasão ou ocupação. Geralmente um grupo de pessoas ligadas à movimentos sociais ingressam em terras particulares ou públicas para ter seu direito de moradia assegurado. Notadamente ocorrem conflitos com os demais particulares e com o poder público. A pergunta a ser respondida é a responsabilidade dos ocupantes de modo precário devem sobre eventuais danos causados em uma APA em decorrência da atividade de busca à moradia.

Essa questão é tormentosa uma vez que existe uma inércia do Estado em assegurar o direito à moradia e as pessoas ligadas a esses movimentos, via de regra, não tem recursos financeiros para reparar o dano. Cairíamos em um dilema a responsabilidade pela inércia estatal anterior e a necessidade de reparação do bem ambiental.

Se entendermos pela Teoria do Risco Integral os ocupantes poderão ser responsabilizados por qualquer dano que ocorrer na APA durante a ocupação ou após quando o dano decorrer de uma atividade ligada a ocupação. A título de exemplo podemos citar o despejo de esgoto doméstico em um determinado córrego.

Já se adotarmos a Teoria do Risco Criado poderíamos utilizar as excludentes de nexo de causalidade para eximir de culpa os ocupantes. Caso o dano decorresse da busca do Direito à Moradia poderíamos responsabilizar o Estado pela omissão anterior de promover o direito fundamental. Tal responsabilização poderia parecer esdrúxula em um primeiro momento, mas se entendermos que o Estado deve promover políticas públicas para consolidação de um direito, contudo não faz, poderá ser responsabilizado por essa omissão. Assim os ocupantes na persecução do seu Direito à Moradia tentam implementar o direito e em decorrência disto causam um dano ambiental, a omissão do Estado foi primordial para que o dano ocorresse. Este instituto de responsabilização do terceiro chamaria culpa exclusiva de terceiro indireta. 
É límpido que está hipótese produziria um ônus econômico no Estado. Enfatizamos que a finalidade da responsabilidade civil é a reparação do dano e no âmbito ambiental deve ser reparado por excelência, uma vez que os direitos lesados são difusos, ou seja, todo povo nacional ou estrangeiro sofreu o dano.

Outro ponto interessante desta teoria de culpa exclusiva de terceiro indireto seria a perpetuação do nexo causal, entende-se que a interpretação do nexo não pode responsabilizar os absurdos, por exemplo, a mãe de um assassino não pode responder por ter gerado seu filho. Entretanto nesse caso não existe uma força desnecessária sobre o nexo causal, uma vez que é direito fundamental e dever do Estado promover a moradia digna.

Os parágrafos $4^{\circ}$ e $5^{\circ}$ do artigo 1228 do Código Civil Brasileiro trazem para o ordenamento jurídico brasileiro a possibilidade de um grande grupo de pessoas desapropriarem indiretamente uma grande área. Ocorre que o artigo $5^{\circ}$ diz que o proprietário da terra deve ser indenizado, mas não informa quem será o responsável. Assim a doutrina dividiu-se em duas correntes, a primeira responsabilizava os ocupantes, tendo em vista o bocado “quem tem o bônus tem o ônus". A segunda coloca o Estado como o responsável pela indenização, uma vez que falhou na implementação do direito fundamental a moradia e os proprietários dificilmente serão ressarcidos no raciocínio da primeira corrente. A segunda corrente foi a privilegiada, assim hoje entende-se da responsabilização do Município ${ }^{23}$. Percebemos que o Estado é responsabilizado por um ato do particular, uma vez que ocorreu uma omissão anterior na questão do direito fundamental à moradia.

O mesmo raciocínio será usado quando ocorrer um dano ambiental em uma APA em terra pública quando o dano tenha ligação direta com a luta pelo Direito à Moradia dos ocupantes. Reafirmamos que essa responsabilização apenas poderá ser utilizada quando o magistrado entender pela Teoria do Risco Criado, uma vez que apenas essa admite uma excludente de nexo causal.

Conforme dito anteriormente percebemos que no limite poderá existir disputa de dois direitos fundamentais. Citamos a fala do ilustre doutrinador Édesio Fernandes em seu texto

\footnotetext{
23 “É entendimento já pacificado, em relação a quem deve pagar a indenização ao expropriado, impondo-se ao Município a responsabilidade, nos casos de imóveis urbanos, e à União, nas hipóteses de imóveis rurais, aquela em razão do art. 182 da Carta Magna de 1988, que impõe ao Poder Público municipal o dever de ordenar o pleno desenvolvimento das funções sociais da cidade e garantir o bem-estar de seus habitantes, e esta em razão dos arts. 184 a 186 da Constituição Federal, bem como a Lei ${ }^{\circ} 8.629$, de 25.02.93, com a redação dada pela Lei $n^{\circ}$ 10.279, de 12.09.01 e Lei Complementar n 76, de 06.07.93”'(ANDRADE, 2003).
} 
Preservação Ambiental ou Moradia? Um falso conflito in Direito Urbanístico: Estudos Brasileiros e Internacionais:

\begin{abstract}
Não há porque demonizar a população ocupantes de áreas de preservação ambiental: é crucial que os governos e a população reconheçam que a promoção de regularização dos assentamentos informais é um direito coletivo, condição de enfrentamento do enorme passivo socioambiental criado ao longo de décadas no país. Para tanto, é preciso que se adote um conceito antropocêntrico de natureza, bem como que se tomem todas as medidas necessárias para a reversão do atual modelo de crescimento urbano segregador e poluidor, de tal forma que as cidades brasileiras possam se tornar cidades ecológicas e sustentáveis do ponto de vista socioambiental (FERNANDES, 2006).
\end{abstract}

A responsabilização civil ambiental em APA pública perpassa pelos meandros para paradigma socioambiental vigente, devendo reconhecer a situação social que o país vive adequando as ações para atingir o Princípio Constitucional da Dignidade da Pessoa Humana.

\title{
7. CONSIDERAÇÕES FINAIS
}

Concluímos que para responsabilizar alguma pessoa deverá existir um juízo sobre um conjunto de variáveis. A primeira será o título de propriedade da terra inserida na Área de Preservação Ambiental, a segunda será a escolha de qual teoria do risco deverá ser aplicada.

A sustentabilidade deve servir como cosmovisão para interpretação do caso concreto. A APA é um instrumento legal que reafirma a necessidade do caráter sustentável dos empreendimentos. Assim, na resolução deste problema devem ser levados em consideração a proteção ambiental e a equidade social, uma vez que a resposta deste problema não deve colocar ninguém em situação de vulnerabilidade social.

Quando a terra possuir domínio privado e a teoria aplicada for a do Risco Integral, o proprietário arcará com a reparação do meio ambiente degradado, sendo que não poderá invocar as excludentes do nexo causal, restando apenas como matéria de defesa a demonstração que não ocorreu o dano ou que não houve conduta.

Se for de domínio privado filiamo-nos à Teoria do Risco Criado, onde o proprietário poderá invocar as excludentes do nexo de causalidade. Também poderá invocar as demais variáveis descritas no parágrafo anterior, uma vez que não há qualquer restrição sobre as matérias rompedoras do nexo causal.

No cenário que a terra é de domínio público sustentamos que a teoria a ser adotada é a do Risco Integral. Nessa situação, os possuidores seriam os responsáveis pela reparação e não deve ser admitida a Culpa de Terceiro, na tentativa de responsabilizar o Estado pela reparação do bem, uma vez que a omissão anterior de implementação de políticas públicas 
habitacionais possibilitou que os moradores adentrassem no imóvel e provocassem um dano ambiental na busca de seu direito fundamental.

\section{REFERÊNCIAS}

ANDRADE, Renata Cristina Othon Lacerda de. A desapropriação judicial no novo Código Civil, Rio Grande, Revista Âmbito Jurídico. Disponível em: http://www.ambitojuridico.com.br/site/index.php?n_link=revista_artigos_leitura\&artigo_id=807. Acesso em: 01 de abr. de 2015.

BEDRAN, Karina Marcos; MAYER, Elizabeth. A. Responsabilidade Civil por Danos Ambientais no Direito Brasileiro e Comparado: Teoria do Risco Criado versus Teoria do Risco Integral. Veredas do Direito, Belo Horizonte, MG, vol. 10, nº19, p. 45-88, Jan/Jul 2013.

BRASIL. Constituição da República Federativa do Brasil, de 05 de outubro de 1988. Diário Oficial [da] República Federativa do Brasil, Brasília, DF, 05 out. 1988. Disponível em: http://www.planalto.gov.br/ccivil_03/constituicao/constituicaocompilado.htm. Acesso em: 01 abr. 2015

BRASIL. Lei no 6938, de 31 de agosto de 1981. Lei da Política Nacional do Meio Ambiente. Diário Oficial [da] República Federativa do Brasil, Brasília, DF, $1^{\circ}$ set. 1981. Disponível em: http://www.planalto.gov.br/ccivil_03/leis/16938.htm . Acesso em: 01 abr. 2015

BRASIL. Lei no 9985, de 18 de julho de 2000. Lei do Sistema Nacional de Unidades de Conservação da Natureza. Diário Oficial [da] República Federativa do Brasil, Brasília, DF, 19 jul. 2000. Disponível em: http://www.planalto.gov.br/ccivil_03/leis/19985.htm . Acesso em: 01 abr. 2015

BRASIL. Lei no 10406, de 10 de janeiro de 2015. Código Civil. Diário Oficial [da] República Federativa do Brasil, Brasília, DF, 11 jan. 2002. Disponível em: http://www.planalto.gov.br/ccivil_03/leis/2002/110406compilada.htm . Acesso em: 01 abr. 2015

BRASIL. Lei no 11977, de 07 de julho de 2009. Programa Minha Casa Minha Vida. Diário Oficial [da] República Federativa do Brasil, Brasília, DF, 08 de jul. 2009. Disponível em: http://www.planalto.gov.br/ccivil_03/_ato2007-2010/2009/lei/111977.htm . Acesso em: 01 abr. 2015

BRASIL. Lei no 13015, de 16 de março de 2015. Código de Processo Civil. Diário Oficial [da] República Federativa do Brasil, Brasília, DF, 17 mar. 2015. Disponível em: http://www.planalto.gov.br/ccivil_03/_Ato2015-2018/2015/Lei/L13105.htm . Acesso em: 01 abr. 2015

BRASIL. Superior Tribunal de Justiça. REsp 232187 / SP. Ação Civil Pública e Dano Ambiental de 23 de mar. 2000. Disponível em: http://www.stj.jus.br/SCON/jurisprudencia/doc.jsp?livre=dano+ambiental+denuncia\%E7\%E3

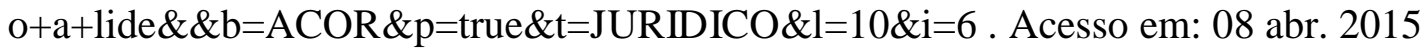


BRASIL. Superior Tribunal de Justiça. REsp 1374284 / MG. Responsabilidade Civil por Dano Ambiental e Teoria do Risco Integral de 27 de agosto de 2014. Disponível em: https://ww2.stj.jus.br/processo/revista/documento/mediado/?componente=ITA\&sequencial=1 $344503 \&$ num_registro $=201201082657 \&$ data $=20140905 \&$ formato=PDF . Acesso em: 02 abr. 2015

CAVAlIERI FILHO, Sergio. Programa de Responsabilidade Civil. São Paulo: Editora Atlas, 2012.

FERNANDES, Edésio; ALFONSIN, Betânia (cord.) Preservação Ambiental ou Moradia? In Direito Urbanístico: Estudos Brasileiros e Internacionais Belo Horizonte. Belo Horizonte Del-Rey, 2006.

FREITAS, Juarez. Sustentabilidade: Direito ao Futuro. Belo Horizonte: Editora Fórum, 2011.

FUNDAÇÃO JOÃO PINHEIRO - FJP. Déficit Habitacional Municipal no Brasil 2010.

Belo Horizonte: p. 1-80, nov.2013.

MARSHALL, Thomas Humphrey. Cidadania, classe social e status. Rio de Janeiro: Zahar, 1967.

ORGANIZAÇÃO DAS NAÇÕES UNIDAS. Declaração de Estocolmo, Estocolmo: 1972. Disponível em: http://www.apambiente.pt/_zdata/Politicas/DesenvolvimentoSustentavel/1972_Declaracao_Es tocolmo.pdf. Acesso em: 01 abr. 2015.

PROGRAMA VILA VIVA, Belo Horizonte. Apresentação do Programa Vila Viva, Belo Horizonte: $2015 . \quad$ Disponível em: http://portalpbh.pbh.gov.br/pbh/ecp/comunidade.do?evento=portlet\&pIdPlc=ecpTaxonomiaM enuPortal \&app=urbel\&tax $=8178 \&$ lang=pt_BR\&;pg=5580\&taxp=0\&. Acesso em: 01 abr. 2015 .

RANGEL, Helano Márcio Vieira. e SILVA, Jacilene Vieira da. O Direito Fundamental à moradia como mínimo existencial, e a sua efetivação à luz do Estatuto da Cidade. Veredas do Direito, Belo Horizonte, MG, vol. 6, nº12, p. 57-78, Jul/Dez. 2013. 